Т. М. Волосовець, О. М. Дорошенко, М. В. Дорошенко Національна медична академія післядипломної освіти імені П. Л. Шупика, м. Київ

\title{
СУЧАСНІ ВИКЛИКИ ТА ВИМОГИ ЩОДО НЕПЕРЕРВНОГО ПРОФЕСІЙНОГО РОЗВИТКУ ЛІКАРІВ-СТОМАТОЛОГІВ
}

\author{
T. M. Volosovets, O. M. Doroshenko, M. V. Doroshenko \\ P. Shupyk National Medical Academy of Postgraduate Education, Kyiv \\ CURRENT CHALLENGES AND REQUIREMENTS FOR CONTINUOUS \\ PROFESSIONAL GROWTH OF DENTISTS
}

\begin{abstract}
Мета роботи - обгрунтувати необхідність неперервного професійного розвитку лікаря-стоматолога.
Основна частина. Нині практична діяльність лікарів у галузі стоматологічної допомоги активно поповнюється новітніми засобами діагностики та лікування патологічних станів порожнини рота. Обсяг медичної інформації для лікарів щорічно оновлюється на третину. Враховуючи зазначене вище, лікар-стоматолог протягом усього професіонального життя має постійно займатися самовдосконаленням та оволодівати новими знаннями.

Висновок. Неперервний професійний розвиток лікарів-стоматологів країни, який відповідає на сучасні виклики часу, є необхідною передумовою поліпшення якості надання стоматологічної допомоги населенню.
\end{abstract}

Ключові слова: лікар-стоматолог; неперервний професійний розвиток; укомплектованість посад лікарів-стоматологів.

The aim of the work - to substantiate the need for continuous professional development of dentists.

The main body. Currently, the practical activities of doctors in the field of dental care are replenished actively with the latest means of diagnosis and treatment of pathological conditions of the oral cavity. One third of the volume of medical information for doctors is updated annually. Considering the abovementioned, dentists have to be constantly engaged in self-improvement and mastering new knowledge throughout their professional life.

Conclusion. Continuous professional development of dental doctors of the nation that responds to the modern challenges of time is a prerequisite for improving the quality of providing dental care to the population.

Key words: dentist; continuous professional growth; staffing of dentists.

Вступ. Стан здоров’я громадян $є$ визначальним критерієм соціально-економічного розвитку країни й основою якості та задовільного рівня життя населення. Стоматологічне здоров'я - одна з важливих складових зазначеного. На сьогодні лікаpi-стоматологи займають третє місце за чисельністю - 26543 особи (забезпеченість на 10 тис. населення складає 4,45) серед інших професійних груп лікарів, поступаючись лише терапевтичній та хірургічній групам. Свідченням важливості цього питання $є$ визначення урядом України у лютому 2017 р. освітньо-наукової спеціальності “Стоматологія" як окремого напряму серед спеціальностей галузі знань “Охорона здоров’я”. Дані Центру медичної статистики МОЗ України вказують на тенденцію щодо зростання потреби

(c) Т. М. Волосовець, О. М. Дорошенко, М. В. Дорошенко у якісній стоматологічній допомозі у дорослих та дітей у більшості областей (за винятком м. Києва, областей Півдня та Сходу) (Ю. В. Вороненко, 2016). Саме тому постійна професійна підготовка лікарівстоматологів $€$ вкрай важливою та визначальною для забезпечення якості надання стоматологічної та у цілому медичної допомоги населенню.

Мета роботи - обгрунтувати необхідність неперервного професійного розвитку лікаря-стоматолога.

Основна частина. За даними Центру медичної статистики МОЗ України, нині країна має достатню мережу стоматологічних закладів охорони здоров'я: так, у 2016 р. стоматологічна допомога надавалась у 1763 установах, з них 197 - самостійні стоматологічні поліклініки та 1566 - інші заклади охорони здоров'я - стоматологічні від- 
ділення чи кабінети (О. В. Павленко, І. П. Мазур, В. Г. Близнюк, 2017).

Укомплектованість посад лікарів-стоматологів у закладах МОЗ України є найвищою у галузі охорони здоров’я та складала у 2016 р. 110,4 \%. На 12 938,25 штатних посадах працює 14250 лікарів-стоматологів. Таким чином різниця між штатними посадами та фізичними особами складає (-1 311,75), що створює умови щодо конкуренції за робоче місце у державних та комунальних закладах охорони здоров'я, особливо у західних областях, що, безумовно, потребує належного рівня знань.

Окрім того, необхідно вказати, що 6898 (26 \% від загальної кількості) лікарів-стоматологів працюють у приватних закладах охорони здоров'я та 7888 (3 \%) лікарів - у закладах охорони здоров’я інших міністерств та відомств.

У той же час необхідно зазначити, що у динаміці кількість лікарів-стоматологів в Україні зменшуєть- ся (рис. 1). Така ж динаміка спостерігається щодо кількості студентів, які навчаються за спеціальністю “Стоматологія”. Якщо у 2009 р. навчалось 10076 осіб, то у 2016 - тільки 8881 особа, тобто зменшення контингенту за останні вісім років відбулось на $12 \%$. При цьому скоротився і прийом на спеціальність “Стоматологія” до 1652 осіб у 2016 р., при аналогічних показниках у 2008 р. понад 2000 осіб.

Необхідно зазначити, що тільки висококваліфіковані стоматологічні кадри здатні забезпечити виконання поставлених завдань щодо забезпечення стоматологічного здоров'я населення. Водночас у закладах охорони здоров'я працює лише 70,4 \% лікарів-стоматологів, що мають лікарські кваліфікаційні категорії, а підвищення кваліфікації щорічно проходять трохи більше 3 тисяч осіб, що складає до 20 \% від загальної кількості лікарів-стоматологів.

Підготовка лікаря-стоматолога - це складний творчий структурований процес, менеджмент якого

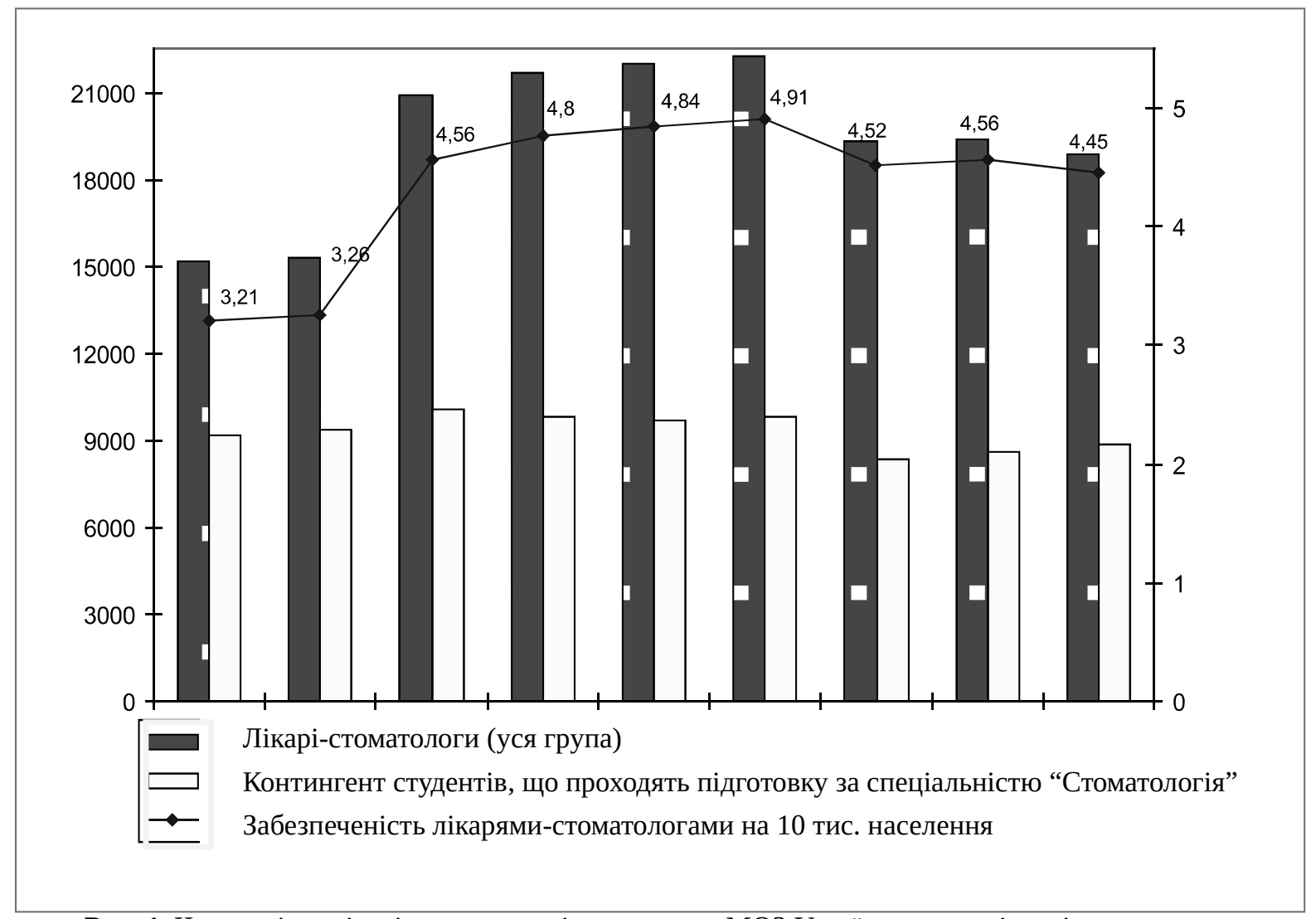

Рис. 1. Чисельність лікарів-стоматологів у закладах МОЗ України, студентів, які навчаються за спеціальністю “Стоматологія” у медичних вишах, та забезпеченість на 10 тис. населення за даними Центру медичної статистики МОЗ України.

здійснюється на основі сучасних стандартів освіти, нормативно-правової бази, відповідно, нового Закону України “Про освіту”, що визначають зміст вищої та післядипломної освіти й організацію на- вчального процесу у закладах вищої освіти та закладах післядипломної освіти.

Особливістю вищої освіти за спеціальністю “Стоматологія” є органічне поєднання отриман- 
ня освітнього рівня магістра стоматології з присвоєнням кваліфікації “Лікар-стоматолог”. Проте, отримуючи достатні теоретичні знання, випускники медичних вишів часто не мають необхідної практики. Водночас пріоритетним є удосконалення підготовки лікаря-стоматолога саме для ланки первинної медико-санітарної допомоги, де зосереджений основний обсяг стоматологічної допомоги.

За даними О. В. Павленка та І. П. Мазур, нині практична діяльність лікарів у галузі стоматологічної допомоги активно поповнюється новими ефективними підходами і способами використання кадрових ресурсів у регіонах. Кваліфіковані стоматологи залучаються до проведення систематичної диспансеризації населення країни шляхом проведення регулярних професійних оглядів порожнини рота. Впроваджуються в повсякденну стоматологічну практику новітні засоби діагностики та лікування патологічних станів порожнини рота, зокрема новоутворень та запальних уражень на тлі імунодефіцитних станів. Обсяг медичної інформації для лікарів щорічно оновлюється на третину. У 2017 р. Міністерством охорони здоров’ я України запроваджена норма застосування міжнародних протоколів діагностики та лікування хвороб. Проводиться робота по підготовці та написанню національних протоколів лікування стоматологічних хворих.

Враховуючи вищезазначене, можна зробити висновок, що лікар-стоматолог протягом усього професіонального життя має постійно займатися самовдосконаленням та оволодівати новими знаннями. У країнах ЄС та світі проводиться жорсткий моніторинг процесу підвищення кваліфікації лікарів. За це несе відповідальність, в першу чергу, сам фахівець, а також професійні стоматологічні асоціації та товариства лікарів. Подібна система неперервного професійного розвитку лікарів-стоматологів має бути реалізована і в Україні.

Нинішня ж атестаційна система мало мотивує лікарів-стоматологів до самовдосконалення. Наказ MO3 України від 07.07.2009 р. № 484 щодо запровадження накопичувальної системи набору балів лікарями у міжатестаційний період теж потребує перегляду.

Отже, неперервний професійний розвиток лікарівстоматологів - це період їх постійного навчання, підготовки, перепідготовки, підвищення кваліфікації й удосконалення, особливо самовдосконалення переважно шляхом on-line, що починається після отримання повної вищої стоматологічної освіти у медичному виші та підготовки в інтернатурі або резидентурі, та продовжується протягом усього професійно активного життя лікаря.

До форм безперервного професійного розвитку лікарів-стоматологів відноситься: проходження курсів інформації та стажування, тематичного удосконалення та передатестаційних циклів; навчання в аспірантурі, докторантурі; читання лекцій для лікарів та середнього медичного персоналу, санітарно-просвітницька робота; ініціативне стажування на робочому місці у провідних вітчизняних та закордонних клініках, зокрема й приватних закладах охорони здоров’я, власна розробка і впровадження нових методів діагностики та лікування стоматологічних захворювань; опрацювання винаходів, керівництво у клініці лікарями-інтернами, лікарями-резидентами та пошукувачами наукових ступенів; видання тез, статей, монографій, підручників, методичних рекомендацій; участь і виступи на профільних з'їздах, конгресах, науково-практичних конференціях, семінарах та вебінарах; викладацька та наукова робота тощо.

Час змін у вищій медичній освіті вимагає від нас зміни дидактичних підходів у побудові архітектури неперервного професійного розвитку лікарів-стоматологів із застосуванням проблемно-орієнтованого навчання на прикладі конкретних клінічних випадків, побудови занять за принципом “ділової командної гри”, широкого використання фантомних класів в удосконаленні оволодіння лікарями практичними навичками.

Безумовно, у подальшій роботі щодо приведення неперервного професійного розвитку лікарів-стоматологів до міжнародних стандартів із використанням доказової медицини необхідно застосовувати кращі міжнародні практики. Так, за результатами опитування дантистів країн ЄС на першому місці щодо важливості щодо їх професійного зростання знаходяться курси підвищення кваліфікації, на другому науково-практичні конференції, на третьому - семінари для практичних лікарів (I. П. Мазур, 2016).

До речі, в Україні провідними вченими-стоматологами Інституту стоматології спільно з кафедрою медичної інформатики Національної медичної академії післядипломної освіти імені П. Л. Шупика спільно із управліннями охорони здоров'я обласних державних адміністрацій запроваджена низка дистанційних регіональних науково-практичних семінарів щодо неперервного професійного розвитку лікарів-стоматологів з метою ознайомлення лікарів 
у регіонах із сучасними науковими розробками у діагностиці та лікування стоматологічної патології.

Важливим напрямом підвищення кваліфікації $є$ також самостійна on-line робота лікарів з міжнародними електронними освітніми платформами, які дають можливість динамічно провести аудит знань лікаря за різними розділами.

\section{Список літератури}

1. Стоматологічна допомога в Україні : довідник / за ред. Ю. В. Вороненка. - К., 2016. - 84 с.

2. Мазур І. П. Сучасний стан стоматологічної допомоги в Україні / I. П. Мазур, О. В. Павленко, В. Г. Близнюк //

\section{References}

1. Voronenko, Yu.V. (Ed.). (2016). Stomatolohichna dopomoha v Ukraini: dovidnyk [Dental care in Ukraine: reference book]. Kyiv [in Ukrainian].

2. Mazur, I.P., Pavlenko, O.V., \& Blyzniuk, V.H. (2017) Suchasnyi stan stomatolohichnoi dopomohy v Ukraini

Електронна адреса для листування: volosovec@ukr.net
Висновок. Неперервний професійний розвиток лікарів-стоматологів країни, який відповідає на сучасні виклики часу, є необхідною передумовою поліпшення якості надання стоматологічної допомоги населенню.

Здоров’я України 21 сторіччя. - 2017. - № 18 (415) (вересень).

[Modern state of dental care in Ukraine]. Zdorovia Ukrainy 21 storichchia - Health in Ukraine in the $21^{\text {st }}$ century, 18 (415) [in Ukrainian]. 